\title{
Towards Optimizing The Use Of Limited Lecture Space At Ardhi University, Tanzania
}

\author{
Khambi Daudi $^{1^{*}}$, Charles Lucian ${ }^{2}$ \\ ${ }^{1}$ Ardhi University, TANZANIA \\ ${ }^{2}$ Ardhi University, TANZANIA \\ * Corresponding Author : k.daudhussein@gmail.com \\ DOI: https://doi.org/10.30880/jts.2018.10.01.006
}

\begin{abstract}
All over the world, the number of students enrolled at higher learning institutions have been on the increase which causes shortage of space, low utilization rates and space mismatch, but many studies have found that most higher learning institutions are not using the space optimally. This study evaluates the effectiveness level of space utilization at Ardhi University"s (ARU) undergraduate classrooms by looking at the level of use and determining how it is impacted by admission of students, conditions of facilities and services and space standards. It found that space use in most ARU's classrooms is affected by the condition and deficiency of some facilities and services, time table re-scheduling, allocating rooms to more than one program at a time (double allocation), class representativese $^{\text {ee }}$ preferences for rooms, by lecturerse preferences for rooms, allocation of rooms to specific programs, current academic situation, and lecture rooms being allocated to students exceeding their capacities.
\end{abstract}

Keywords: Space management, Space utilization, Effectiveness, Multi-dimensional evaluation, Higher learning institutions

\section{Introduction}

Space management in higher learning institutions is more critical compared to other institutions, therefore teaching and learning spaces need to be responsive to the changing demands of a leading university; designed flexibly and planned on the basis of function in order to encourage effective utilization (SMG, 2006). All over the world, there is an overwhelming pressure on higher learning institutions to admit an increasing number of students attributed mainly by students applying for, and academic activities that take place inside Higher Learning Institutions (Rahman et al., 2015). Globalization has also positively impacted the global demand for higher education (Altbach, 2006); and because higher education is becoming a dynamic and global enterprise, the strategic management of higher education facilities is also becoming increasingly complex (Marmolejo et al., 2007).

Nonetheless, the increase is in the context of enormous reductions in the availability of institutional resources because more efforts have been emphasized at the expansion of enrolments without expanding the resources that the institutions need. However, utilization of these resources is not evaluated apparently because it is assumed that, once available; resources are put to optimum use (Ssempebwa, 2011). This is why many institutions claim to have a lack of learning space while it is that, they are not optimizing the use of physical resources (Che Ani et al., 2012).

Space and facilities management is to be prioritized and have to be managed efficiently otherwise it will bring negative impacts to both the end-user of the space in HLIs as well as their administrative (Abdullah et al., 2012a). After all, the costs which are related to the physical resources are the second most important budget after staff salary in higher learning institutions (Abdullah et al., 2012a; Che Ani et al., 2012; Ibrahim et al., 2012; Ibrahim et al., 2011a; Space Management Group, 2006). 
(C) Universiti Tun Hussein Onn Malaysia Publisheres Office

\section{JTS}

http://penerbit.uthm.edu.my/ojs/index.php/jts
Journal of Techno Social

But, until now most of higher learning administrations have yet to understand the role and contribution of these physical resources to HLI organizations (Ibrahim et al., 2011a); this is one of the reasons why problems exist because HLIs do not essentially prioritize space management (Abdullah et al., 2012a; Rahman et al., 2015).

While space managers are under pressure to make a more efficient use of the available space, better management is hampered because there does not appear to neither be a good understanding within space management (near-term planning) of why space becomes scarce, nor, a good basis within space planning (long-term planning) of how best to accommodate the expected low utilizations (Beyrouthy et al., 2007).

There is a need for higher learning institutions to translate space management from the organization "s objectives into spatial relationships of its functions, together with the needs of the people who perform the functions; within a given or proposed accommodating space (Abdullah et al., 2012a).

Space needs to be optimized rather than maximized for use (Ssempebwa, 2011). There is a balance between minimizing cost and meeting the pedagogical and research needs of staff, and the learning and support needs of students; this balance will vary among HLIs, but when decisions are made about what is the optimum level, it is advisable to be aware of the opportunity costs of low utilization because effective utilization of space also creates a good match between space needs, space provision, and helps to improve the staff and student experience (SMG, 2006).

\section{Literature Review}

\section{Managing Space}

Evaluating space utilization in higher learning institutions involves a series of many activities which are interrelated to one another. There is no one specific model for performing the evaluation which has been stated to be reliable in all circumstances. However in most literature, issues of efficiency and effectiveness, should be brought to the attention of top university's management (NCU \& HEFCE, 2002); then academic community, other users of the estate and interested parties if maximum benefit is to be gained, while being actively and intensively managed in order to get real improvements (HEFCW 2002).

Ibrahim et al (2012) and Fusch (2012) suggest the need to develop a management committee, a model or technique of managing the space and ensuring that employees know and understand the management of space, who will establish and adopt a space management strategy, generate adequate utilization data rates, implement space charging, computerized central timetables and cost effective reallocation methods of space (NAO, 1996); nevertheless, they have to understand the concepts of space inventory, measuring utilization, and future space needs (Abdullah et al., 2012a).

\section{Managing Space Adopting an Approach}

Effectiveness in the space use has to determine how space will be employed from the moment it is conceptual up to the time it is delivered and put to use. Subsequently, throughout years different approaches have been developed and employed by HEIs to evaluate space use from which some use timetabling method for their surveys and others through inspections (Abdullah et al., 2012b). Rahman et al. (2015) termed these approaches as the model of space utilization which was simplified by Ibrahim et al. (2011b) to consist of a leader of objectives/purpose, information and communication strategy, practical tools for performing the measurements, analysis and interpretation. However in any of these cases, there has to be a "management champion with high-level of commitment within the organisation to progress change, to drive it on and prevent it from lapsing over a protracted time period" (NCU \& HEFCE, 2002).

\section{Performing Measurements}

Space utilization is usually defined as a measure of how rooms and spaces are used in terms of how often, when, and how many people are in them (SMG, 2006). To facilitate these measurements, accurate information about the rooms is integral. It has to include information on room ownership and room types (TEFMA, 2009); types of space (Abdullah et al., 2012a); while using various problem instances and optimization algorithms which have to also include information related to timeslots, total number of students, time tabling and splitting (Beyrouthy et al., 2007).

The information obtained will enable thorough examination of audit data analyzed by the room performance indicators termed as Utilization rate, Frequency rate and Occupancy rate (NAO 1996; SMG 2006; TEFMA 2009; Ssempebwa 2011; Abdullah et al 2012b). These are the key aggregates for evaluating space utilization in a class room (Che Ani et al., 2012). 
However, identifying the performance alone does not point out where the sources of deficiencies are (NAO, 1996; SMG, 2006); yet, may provide unrealistic results (Beyrouthy et al., 2007); because they do not allow computation of the intake capacity of teaching space (Ssempebwa, 2011). Although, they give a broad indication of intensity of uses, but neither the headline rates nor the raw data will in them still be enough to effect institutional change (SMG, 2006); after all, details of how to implement these tools and their effectiveness, are not well-understood by the sector as a whole (NCU \& HEFCE, 2002).

To facilitate such change, HLIs need to perform statistical studies to reveal underlying threshold phenomena (Beyrouthy et al., 2007); by analyzing and interrogating the actual patterns of data collected (Space Management Group, 2006; TEFMA, 2009; Ssempebwa, 2011; Che Ani et al., 2012). This analysis is potential because it identifies the mismatch between demand and provision if it goes further assessing students contact hours, compared to actual utilisation levels and will act as a useful starting point in assessing space needs (NCU \& HEFCE, 2002).

\section{Introducing a multi-dimensional evaluation}

Progress in optimizing space will also arise from following a multidisciplinary approach; addressing the architectural, policy \& curricula, geographical and societal factors that are pertinent to the rate of use of teaching space; it has to address the availability of human and material resources that complement teaching and learning process (Ssempebwa, 2011).

A classroom can be poorly utilized due to its physical attributes: its condition, size, and design; an oversupply of similar facilities; insufficient capacity; too much capacity; wrong location or changing teaching patterns (TEFMA, 2009). Ssempebwa (2011) found that, in Uganda physical resources with better teaching facilities and services experience more utilization compared to others. This raises the need to also look at the quantity, quality and adherence of these resources to minimum standards because they affect the quality of education (Asiyai, 2013).

\section{Research Methodology}

This study was conducted during the working hours of week days from Monday to Friday. Master timetable was requested from the Directorate of Planning and Development (DPD) of Ardhi University (ARU), and used to observe how learning space has been allocated compared to true/actual use. A total of 52 undergraduate classrooms were examined on UFO calculations, and mesurements to determine adherence of classrooms to minimum standards was done in 30 rooms only excluding all studios and laboratories. An explanatory sequential mixed method approach was employed to evaluate how the objective factors (enrollments, utilization rates, buildings ${ }^{\text {ee }}$ facilities and space standards) influence space utilization quantitatively then using results from management's perceptions to explain more about quantitative results. Semi-structured interviews were conducted with Directorate of Planning and Development (DPD), and the Directorate of Estate Services (DES).

Space use level was evaluated from the utilization, frequency and occupancy (UFO) performance indicators in Table 1, and the effectiveness level in Table 2 adopted from TEFMA (2009).

However, TEFMA's effectiveness levels are un-categorical, making it difficult to clearly classify the utilization intervals of rooms. This led to embedding with those provided by Che Ani et al (2012) and Rahman et al (2015) in order to produce more detailed categories of utilization rates as displayed in Table 3.

Table 1: Space use performance indicators (TEFMA, 2009, p.29)

\begin{tabular}{ccc}
\hline No. & Item & Formula \\
\hline 1 & Frequency Used & $\frac{\text { Hours used }}{\text { Hours available }} \times 100 \%$ \\
2 & Occupancy & $\frac{\sum \text { Total number of students }}{\text { Capacity of room } \times \text { Hour usage }} \times 100 \%$ \\
3 & Utilization & $\frac{\text { Room Use Frequency } \times \text { Room Occupancy }}{100}$ \\
\hline
\end{tabular}

Table 2: Effectiveness level for space use (TEFMA, 2009, p.31)

Usage $\quad$ Effectiveness Level (\%)


Frequency Used

Occupancy

Utilization
75

75

56

Table 3: Utilization intervals and their levels

\begin{tabular}{cccc}
\hline No. & Use interval & Use range (\%) & $\begin{array}{c}\text { Occupancy and frequency } \\
\text { range (\%) } \\
\text { (CheAni et al., 2012) }\end{array}$ \\
\hline 1 & Minimum & $0-20$ & $0-50$ \\
2 & Optimal & $20-40$ & $51-75$ \\
3 & Maximum & $41-80$ & $76-100$ \\
4 & Critical & $81-100$ & $>100$ \\
\hline
\end{tabular}

Data collection

Data was collected through participatory observation, which enhanced interaction with space users. Utilization survey form adopted from Abdullah et al (2012a), was modified and used to record the actual use of space and space standards; condition assessment forms were used to collect data on the availability, condition and defects of facilities. The data was used to establish how these facilities affect space use. Interview responses were tape recorded and noted down to increase the accuracy during data analysis.

\section{Analysis}

The utilization rates show that the use of undergraduate lecture rooms ranges from $0 \%-48.7 \%$; this has fallen between under to low utilized. Room 5 is the room with the highest utilization rate of $48.7 \%$. Room 2, 17, 25, 31.2, 32, $34,51,52,53$ and 54 have the lowest utilization frequency and occupancy of $0 \%$. The level to which rooms are frequently used is at an average of $38 \%$ also meaning that rooms are not frequently utilized; with room 24 and 18 having the highest frequency rates both tieing at $84 \%$. Average occupancy rate has fallen at $41 \%$ describing that most classrooms are also occupied with a small number of total students in an entire week. However room 5 has the highest occupancy rate of $132 \%$.

Figure 1 presents the highest to the lowest utilization rates of all lecture rooms used by undergraduate students at Ardhi University as a result of the audit conducted in Semester II of academic year 2017/18.

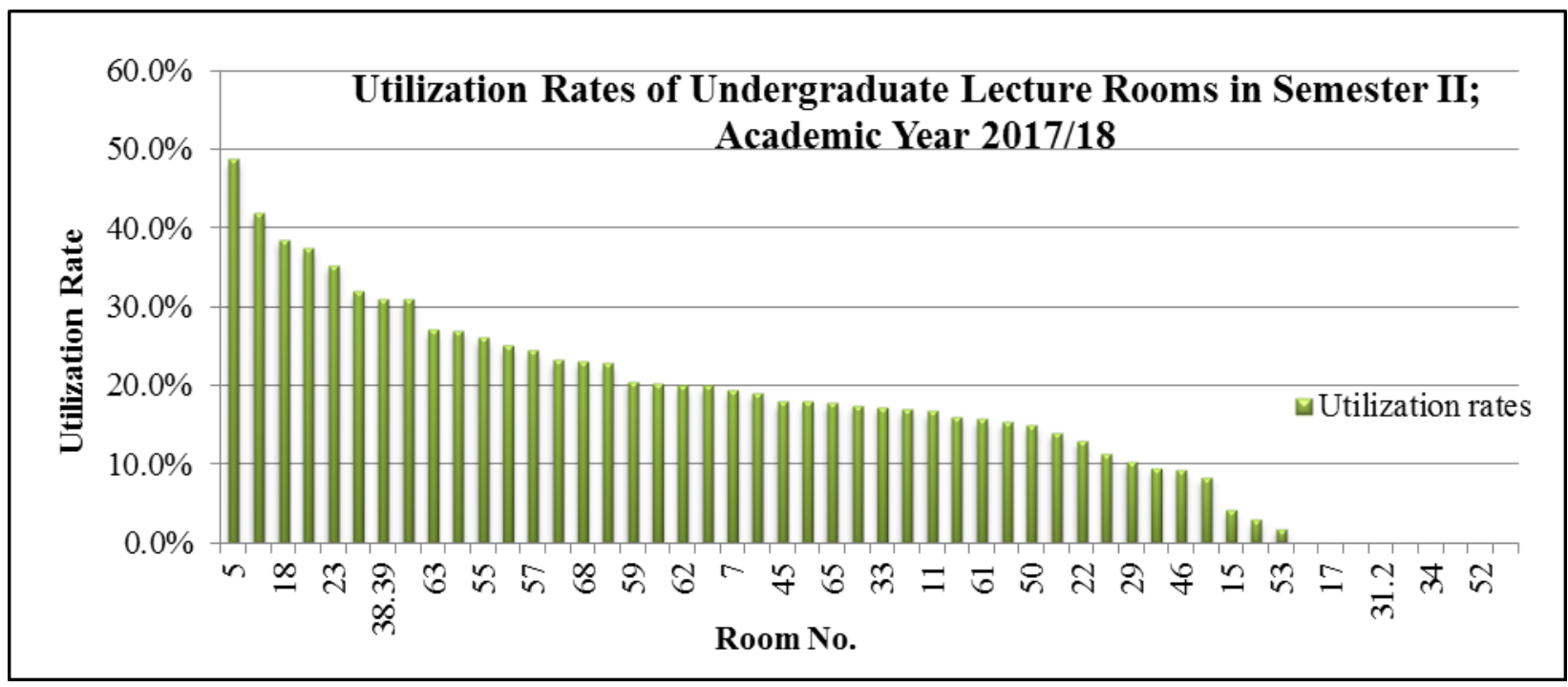

Figure 1: Utilization rates of undergraduate lecture rooms in Ardhi University

Some rooms are highly utilized compared to others, because they are used more frequently, while others are overwhelmed by the total number of students using them. Yet, there are other rooms which have a balance between the 
total number of students using them in a week and their frequency of use. And lastly are those which are not occupied completely which have the least utilization rates (Table 4).

Table 4: Utilization intervals results of lecture rooms in Ardhi University

\begin{tabular}{|c|c|c|c|c|c|c|}
\hline No. & $\begin{array}{c}\text { Use } \\
\text { interval }\end{array}$ & $\begin{array}{l}\text { Use range } \\
(\%)\end{array}$ & Use (F) & $\begin{array}{l}\text { Occupancy } \\
\text { and frequency } \\
\text { range }(\%)\end{array}$ & (F) & $\begin{array}{l}\text { Frequency } \\
\text { of use (F) }\end{array}$ \\
\hline 1 & Minimum & $0-20$ & 36 & $0-50$ & 41 & 35 \\
\hline 2 & Optimal & $20-40$ & 14 & $51-75$ & 7 & 15 \\
\hline 3 & Maximum & $41-80$ & 2 & $76-100$ & 2 & 2 \\
\hline 4 & Critical & $81-100$ & 0 & $>100$ & 2 & 0 \\
\hline 5 & TOTAL & & $\mathrm{N}=52$ & & $\mathrm{~N}=52$ & $\mathrm{~N}=52$ \\
\hline 6 & AVERAGE & & $17 \%$ & & $41 \%$ & $38 \%$ \\
\hline
\end{tabular}

\section{Findings and Discussion}

Ardhi University has increased enrollments because of the increase in students admitted for higher learning in the University (Table 5). This increase does not affect space utilization because UFO results show that the university has vast number of learning spaces but they are not used effectively. Most space used by undergraduate students is underutilized. (N/d - No data obtained)

Table 5: Enrollments and Admission Records from Academic Year 2006/07 - 2017/18

Academic year

\begin{tabular}{llllll}
\multicolumn{2}{l}{ Enrollments } & \multicolumn{3}{l}{ Admission } \\
Male & Female & Total & Male & Female & Total \\
1140 & 226 & 1366 & N/d & N/d & N/d \\
1108 & 216 & 1324 & N/d & N/d & N/d \\
1193 & 310 & 1503 & 471 & 170 & 641 \\
1481 & 515 & 2126 & 549 & 245 & 794 \\
1926 & 725 & 2651 & 707 & 206 & 913 \\
2187 & 1006 & 3195 & 550 & 302 & 852 \\
2393 & 1156 & 3549 & 684 & 275 & 959 \\
2459 & 1208 & 3667 & 638 & 391 & 1029 \\
2353 & 1347 & 3700 & 699 & 451 & 1150 \\
2373 & 1398 & 3771 & 642 & 381 & 1023 \\
N/d & N/d & N/d & N/d & N/d & N/d \\
2383 & 1570 & 3953 & N/d & N/d & N/d
\end{tabular}

Source: DPD reports $(2009$ - 2018)

$4 \%$ of all rooms used for undergraduate programs are used at maximum. This is caused by presentations by different programs which occur twice in every week; furthermore, the total number of students in the programs occupying these rooms is large, because the students are combined in a single room with a smaller capacity than the class size; the students share some courses, so during lectures they are combined in a single lecture theatre for the lesson.

$27 \%$ of the rooms have a match between total numbers of students occupying the classes in a week with their capacities, and they are utilized more frequently.

Lastly $69 \%$ of the rooms have low utilization rates. Low utilization rates occur at ARU because, during the time of the timetable structuring process; a single classroom is being allocated to more than one program at the same time; bigger class size is allocated to a small capacity room while classrooms with bigger capacities are left unused, and most of the users do not use classrooms the way they have been allocated on the master timetable, rather whenever they are found unoccupied and containing a capacity able to carry that particular class size.

Nonetheless, lecturers make good use of classrooms close to their offices in which they prioritize them compared to those which are far. But also, sometimes lecturers mistake the allocated class with another but because the mistaken class was found unused the lesson is conducted in that particular class. And they also re-schedule the timetable due to un-forecasted emergencies that take place later after the final master timetable has been released.

Academic situation currently taking place in the university during the audit period also affects the utilization rates of classrooms. Audit period of this study was during a time where many programs had semester tests. Capacity of students during normal lecture sessions and during tests \& exams of the same class vary; caused by low attendance rates of students during normal classes. During tests, it becomes necessary for a class to look for an additional room to 
split into, or shift the whole class to a bigger room while the room that has seemed not enough is the actual room allocated to that class by the master timetable. Also when the syllabus is covered, classrooms are left unoccupied.

Class representatives (CRs), request lecturers to re-schedule evening lessons to be attended during the day time in empty rooms causing a lot of classes to be left unoccupied during the evening sessions from 5:20 pm to 7.20 pm. They also request to reschedule when their fellow students with carry-over subjects are subjected to more than one lesson at a single time in the timetable. However, the point of carry-over students, leads to time table rescheduling and not low utilization rates. The problem is that re-scheduling the timetable makes classes unused while the master timetable denotes the classes to be occupied at that particular time.

Their preferences in choosing which class to use for a lesson also leads to low use rates of certain classes compared to others. Most CRs prefer classrooms with better facilities and services in those particular buildings which they frequently use.

In fact, a classroom can be poorly utilized due to its physical attributes like condition (TEFMA, 2009); And if it happens a class is used despite having poor facilities and services, then it will create uncomfortable learning environment which will interfere with the student's focus, that ultimately affect the quality of learning; because environmental influences are also a contributing factor to the failure or excellence of a student (Che Ani et al., 2012).

\section{Impacts of conditions of facilities and service to space use at Ardhi University}

The conditions of the facilities and services affect the utilization rates of some classrooms in ARU. Although the defected facilities were identified and found to lead to a class shift, but the shift would depend on the learning process of that particular lecture. These rooms were found to be left unoccupied mainly because they have defected sockets, and dirty writing boards. A lecture session which will involve the use of projectors or writing on the board during the learning process, it will not use these rooms. However from the utilization rates, most of these rooms fall among optimally utilized rooms despite being left unused whenever obsolete for function. This is because other programs which do not need projectors or writing in these specific rooms, they use them when they are allocated, or when they find them empty. Some other classes are seldom preferred due to lack of washrooms, poor design of the room and design of fixtures installed which do not allow seats to be shared (Figure 2).

Impacts of space standards to space use at Ardhi University

All lecture rooms have desks and chairs permanently fixed on the ground; all with the same type and size of fixtures as displayed on the left image of Figure 2, except those in room 29 because with a different design as displayed on the right image of Figure 2.

All the classes at ARU have fallen in the unaccepted category from the standards provided by the Tanzania Commission for Universities - TCU (2014). TCU's unaccepted space standard is $<0.8 \mathrm{~m} 2$ for learning space in all lecture rooms and theatres, and $<10 \mathrm{~m} 2$ and $<20 \mathrm{~m} 2$ for teaching space in lecture rooms and lecture theatres respectively.

In the lecture rooms, each seat has $0.63 \mathrm{~m} 2$ per student, with room 29 having a total of $0.54 \mathrm{~m} 2$ per student. With the teaching space, all the classes have rate above „Good ${ }^{\text {ee }}$ with others rating more than the ideal value. This means that, most lecture rooms have large teaching spaces compared to spaces per student.

Although the findings show that there are no proper standards for classrooms at the campus university level; they have no implications on the utilization rates because students are not affected by the space provided.

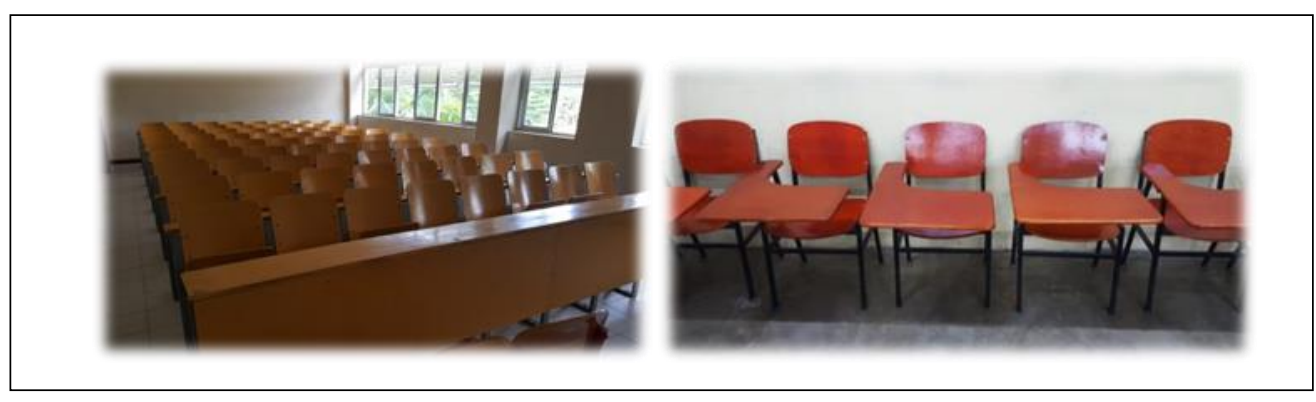

Figure 2: Design of seats in Ardhi University's lecture rooms

\section{Recommendations}

Ardhi University needs to conduct intensive space utilization surveys to determine the utilization rates of all the classrooms in the university ranging from ordinary level diploma to $\mathrm{PhD}$ level, with the audit taking place in the middle of a semester or after approximately 5-8 weeks after the semester has begun because these are the times when the utilization of the rooms are at peak. 
Because classrooms experience congestions, it does not mean that the space is not enough. After all, constructing new facilities does not solve space deficiencies in an organization, rather optimizing the space that is already available by ensuring that classrooms are utilized at highest but without compromising the standards (Ssempebwa, 2011). When new facilities are constructed, ARU needs to add lecture theatres of more than $250+$ seats and not classes with less than 180 seats, because there is a deficiency of large learning spaces.

The University also needs to adopt a better space utilization practice in which the structure of the master time table will not put breaks in the rooms; rather, breaks are given to the students as it will be displayed in their specific program timetables. The university could also rent out space to be used during the holidays as it would add some revenue to the university"s income.

There is also a need for the university to pay more attention and time for the university's master timetable structuring process; to help solve the presence of voids; ensuring issues such as double allocation and allocating a class size mismatching a class capacity are dealt with before the final draft is produced. After producing the preliminary drafts of the master timetable, effective communication should be implemented between the DPD, timetable coordinators, and lecturers. It would be best if timetable coordinators communicate with the lecturer more than the students because lecturers recommend class use in real time; while students recommend based on appearance and preferences.

The facilities and services especially those complementing the learning process need to be regularly inspected and those identified with defects need to be repaired quickly.

Users (students) need to be reminded on the importance of the surrounding they use for learning to their academic excellence. Most of students are not aware that "environmental influences are also a contributing factor to the failure or excellence of a student" (Che Ani et al., 2012). They need to be reminded on the importance of having a clean and healthy environment. They should be made aware that the lecture buildings and their rooms are provided by the University for them. So they need to take care of these facilities and not see them as free good. The university could act by providing seminars to every new intake of first year students during the orientation week; explaining to them how to maintain a healthy learning environment; Dos and Don'ts; how and when. It should also provide consequences of neglecting such actions.

The university needs to allow learning spaces allocated to specific programs to be used by other programs whenever necessary, considering the fact that the space standards of those particular rooms are not be compromised.

The „Space Charging Modelee can be employed at Ardhi University. It is a tool for optimal space management accepted and used by most facility experts today. Through space charging, all parts of the occupied space are charged, and when they are not occupied at times which they are supposed to be occupied, the user is charged some fee for the space they left unused for nothing, so that they should not see space as a free good.

Such a tool could be used to regulate the utilization rates of space. It would help to reduce space wastage and increase awareness to space users. NAO (1996) stipulates four elements in Space Charging concept which are; space to be charged, amount to be charged, mechanism for cost and the source of payment for the charge. It was certified as the best method in 1996; however, many facilities experts today say that this method is the best management tool for space optimization (Marsh \& Griffith 1985; SMG 2006; Ibrahim et al 2011a; Ibrahim et al 2011b; Ibrahim et al 2012).

Finally, the space management evaluation must be addressed properly in order to increase the utilization rates. Abdullah et al (2012a) proposed the criteria presented in Table 6 that work best for effective space management in higher learning institutions. From the Table they suggested attention to be focused on staff members and their space management knowledge; classroom arrangement; use of software; managing space during breaks, and regularly evaluating space use.

Table 6: Criteria for effective space management in higher learning institutions

\begin{tabular}{ll}
\hline \multicolumn{1}{c}{ Item } & Method for effective space management \\
$\begin{array}{l}\text { Staff involvement and } \\
\text { competency }\end{array}$ & $\begin{array}{l}\text { Depends on the size of the faculty } \\
\text { Staff or officer involved in space management should have relevant knowledge on } \\
\text { space management }\end{array}$ \\
\hline Classroom arrangement & $\begin{array}{l}\text { Consider the ratio between classroom capacity and number of student. } \\
\text { Traveling time between two rooms should be minimized }\end{array}$ \\
\hline Use of software & $\begin{array}{l}\text { If software is used, it is necessary to have at least a staff that can master the use of } \\
\text { software to make sure that the software can play its role. }\end{array}$ \\
\hline $\begin{array}{l}\text { Managing space during } \\
\text { break }\end{array}$ & $\begin{array}{l}\text { Rent out the space in order to increase room frequency and generate income from } \\
\text { space. } \\
\text { Cooperate with other organizations that need venue for organizing events. }\end{array}$ \\
\hline $\begin{array}{l}\text { Space management } \\
\text { evaluation }\end{array}$ & $\begin{array}{l}\text { Current space management system must be reviewed and evaluated regularly. } \\
\text { The frequency of review should base on the ability of the university. }\end{array}$ \\
\hline
\end{tabular}

Source: (Abdullah et al., 2012a, p.18) 


\section{Conclusion}

In this study, the value of space is the underlying assumption. Value of a facility or service is the one attained when function of a facility or service is met within the lowest possible costs. Because space has value, and value is identified in monetary terms, therefore wasting space is wasting money.

So far, space is money because it has implications on operation costs of any facility as it has been identified to be the second highest budget in institutional operations after staff salary (Abdullah et al., 2012a; Che Ani et al., 2012; Ibrahim et al., 2012; Ibrahim et al., 2011a; Space Management Group, 2006; NAO, 1996). Therefore, the more space used, the more costs are imposed for servicing a building example cleaning, energy [lighting, mechanical ventilating, electricity, etc.], maintenance \& repairs, managing, operating and others.

This raises a need for space to be used at its optimal because under-utilization wastes space; it reduces the effectiveness of the space hence more costs are imposed on space that is rarely used; furthermore, over utilization overwhelms the space and its surroundings and may lead to poor ventilation, discomfort of users, poor visual impression, congestion, poor environmental aesthetic effect, regular maintenance \& repair, high deterioration rate of building materials, facilities, furniture $\&$ fittings and high use of building services.

Ibrahim et al (2012) stated that, "space management for institutes of higher education are very critical, therefore, space and facilities management have to be the main agenda and need to be managed efficiently and appreciated wisely". Moreover, effective and efficient management of these resources can not only reduce operating costs of a facility, but also sustain the physical and the function of the spaces. Therefore, "all related units should play their roles in meeting the needs of current ways of life, to sustain our resources, including existing building spaces" (Abdullah et al., 2012a).

\section{Acknowledgements}

The authors gratefully acknowledges the supervision and helpful comments made by other anonymous referees who reviewed an earlier version of this paper, and all relevant parties who have a direct or indirect contribution to the success of this research.

\section{References}

Abdullah, S., Ali, H.M., Awang, M. \& Rahman, M.S.A., 2012b. Classroom Management: Measuring Space Usage. In International Congress on Interdisciplinary Business and Social Science. Johor Bahru, 2012b. Elsevier Ltd.

Abdullah, S., Ali, H.M. \& Sipan, I., 2012a. Benchmarking space usage in higher education institutes: Attaining efficient use. Journal of Social Technology, 4(1).

Adedeji, R.D., Okemakinde, T. \& Ssempebwa, J., 2008. Teaching resources utilisation and academic performance in technical colleges in Oyo State, Nigeria. Kampala International University Research Digest, 1, pp.100-4.

Altbach, P.G., 2006. The perils of internationalizing higher education: An Asian perspective. In P.G. Altbach, ed. International Higher Education: Reflections on Policy and Practice. Boston: Boston College Centre for International Higher Education.

Amaratunga, D. \& Baldry, D., 1998. Post-occupancy evaluation of higher education teaching spaces- A methodological approach. Yorkshire: Research Centre for Built and Human Environment.

Amaratunga, D. \& Baldry, D., 2000. Assessment of facilities management performance in higher education properties. Facilities, 18(8), pp.293-301.

Ansoff, I., ed., 1969. Business Strategy: Selected readings. Baltimore: Penguin Books.

Asiyai, R.I., 2013. Challenges of Quality in Higher Education in Nigeria in the 21st Century. International Journal of Educational Planning \& Administration, 3(2), pp.159-72.

Athapaththu, H., 2016. An Overview of Strategic Management: An Analysis of the Concepts and the Importance of Strategic Management. International Journal of Scientific and Research Publications, 6(2), pp.124-7.

Atkin, B. \& Brooks, A., 2009. Total Facilities Management. 3rd ed. Chichester: John Wiley \& Sons Ltd.

Aziz, N.D., Nawawi, A.H. \& Ariff, N.R.M., 2016. ICT Evolution in Facilities Management (FM): Building Information Modelling (BIM) as the Latest Technology. In Annual Serial Landmark International (ASLI) Conference on Quality of Life. Medan, 2016. Elsevier Ltd. 
Beyrouthy, C., Burke, E.K., Landa-Silva, D.J.M.B. \& McMullan, P., 2007. Towards improving the utilisation of university teaching space. Journal of Operational Research Society, 58(11), pp.130-43.

Booty, F., ed., 2009. Facilities Management. 4th ed. Oxford: Elsevier Ltd.

Carpenter, C. \& Oluafa, A., 1995. Post-Occupancy Evaluation of Buildings and Development of Facility performance criteria. Post-Occupancy Evaluation of Buildings and Development of Facility performance criteria, 1(2), pp.77-81.

Chandler, A., 1962. Strategy and structure: Chapters in the history of American industrial enterprise. Cambridge Mass: MIT Press.

Che Ani, A.I., Tawil, M.M. \& Abdullah, N.G., 2012. Frequency index for learning space in higher education institutions. Procedia - Social and Behavioral Sciences, 56(8), pp.587-93.

Creswell, J.W., 2014. Research Design: Qualitative, Quantitative and Mixed Methods Apoaches. 4th ed. Washington DC: SAGE Publications, Inc.

Daigneau, W., 2006. Facilities Management Practices in Higher Education. [Online] Association of Higher Education Facilities Officers (APPA) Available at: https://www.appa.org/./FM112206\%20-\%20Feature [Accessed 20 May 2018 ].

Dess, G., Lumpkin, G. \& Eisner, A., 2007. Strategic management. 3rd ed. New York: McGraw-Hill.

Difficile, M., 2010. Space saving vs. space optimization. [Online] Available at: https://forum.wordreference.com/threads/space-saving-vs-space-optimization.1764202/ [Accessed 27 May 2018].

Directorate of Planning and Development (DPD), 2010. Facts and Figures 2009/10. Dar es Salaam: Ardhi University.

Directorate of Planning and Development (DPD), 2011. Facts and Figures 2010/11. Dar es Salaam: Ardhi University.

Directorate of Planning and Development (DPD), 2012. Facts and Figures 2011/12. Dar es Salaam: Ardhi Universirty.

Directorate of Planning and Development (DPD), 2013. Facts and Figures 2012/13. Dar es Salaam: Ardhi University.

Directorate of Planning and Development (DPD), 2014. Facts and Figures 2013/14. Dar es Salaam: Ardhi University.

Directorate of Planning and Development (DPD), 2015. Facts and Figures 2014/15. Dar es Salaam: Ardhi university.

Directorate of Planning and Development (DPD), 2016. Facts and Figures 2015/16. Dar es Salaam: Ardhi University.

Drucker, P.F., 1954. The Practice of Management. New York: Harper and Brothers.

Facility Management Association of Australia (FMAA), 2012. Facilities Management: A good practice guide. [Online] Melbourne: Facility Management Victoria Property Limited (1.0) Available at: https:/www.melbourne.vic.gov.au/sitecollection-documents/good-practice-guide-facilities-management.pdf [Accessed 24 May 2018].

Fairholm, M. \& Card, M., 2009. Perspectives of strategic thinking from controlling to embracing. Journal of Management and organization, 15(1), pp.17-30.

Federal Real Property Council (FRPC), 1998. Facilities Maintenance Assessment and Recommendations. Facilities Management Systems Partnership (FMSP).

Fusch, D., 2012. Seeing Success in Space optimization. [Online] Academic Impressions Available at: https://www.academicimpressions.com/seeing-success-in-space-optimization/ [Accessed 27 May 2018].

Hakansson, H. \& Snehota, I., 2006. The concept of business strategy. Scandnavian Journal of Management, 22(3), pp.256-70.

Higher Education Funding Council for Wales (HEFCW), 2002. Space Management: A Good Practice Guide. Swansea: ELWa (Education and Learning Wales) University of Wales. 
Ibrahim, I., Wan Yussoff, Z. \& Bilal, K., 2012. Space management: A study on space usage level in higher education institutions. Procedia - Social and Behavioral Sciences, 47, pp.1880-7.

Ibrahim, I., Wan Yussoff, Z. \& Sidi, N.S., 2011a. Space charging model: Cost analysis on classrooms in higher education institutions. Procedia - Social and Behavioral Sciences, 28, pp.246-52.

Ibrahim, I., Yusoff, W.Z.W. \& Sidi, N.S.S., 2011b. A Comparative Study on Elements of Space Management in Facilities Management at Higher Education Institutions. In International Conference on Sociality and Economics Development. Singapore, 2011b. LACSIT Press.

International Facilities Management Association (IFMA), 2011. International Facilities Management Association. [Online] Available at: https://www.ifma.org [Accessed 19 May 2018].

Isa, A. \& Yusoff, W.Z.W., 2015. State of Physical Facilities of Higher Education Institutions in Nigeria. International Journal of Scientific and Research Publications, 5(4), pp.1-5.

Kerns, J.A., 2011. What is a condition survey. [Online] QproQ Engineering Inc. Available at: http://www.warrantydeedtemplate.com/form/100409720- [Accessed 26 May 2018].

Kothari, C.R., 2004. Research Methodology: Methods and Tehniques. 2nd ed. New Delhi: New Age International (P) Ltd., Publishers.

Marmolejo, F., Gonzalez, R., Gersberg, N. \& Campos, P., 2007. Higher Education Facilities: Issues and Trends. [Online] National Institute of Building Sciences Available http://lysander.sourceoecd.org/vl=2653475/cl=14/nw=1/rpsv/cgi- $\quad$ bin/wppdf?file=514s50q4xjkk.pdf [Accessed 30 December 2017].

Marsh, D.C. \& Griffith, W.J., 1985. Management of the space resource, space cost budgeting. Council of Educational Facility Planners International Journal.

Mathenge, M., 2015. AarchiDATUM. [Online] Available at: http://www.archidatum.com/projects/ardhi-universityuniversity-of-dar-es-salaam/ [Accessed 23 June 2018].

Mintzberg, H., 1987. The strategy concept: Five P's for strategy. California Management Review, 30(1), pp.11-24.

Mursky, C., 2015. Handbook for Institutions Seeking Reaffirmation of Accreditation. [Online] The Teaching Channel Available at: https://www.uno.edu/quality./QEP-2.12-Resource-Manual.pdf [Accessed 19 May 2018].

Musa, M.F. \& Baharum, Z.A., 2012. Higher Education Physical Assets and Facilities. In ASEAN Conference on Environment-Behaviour Studies. Bangkok, 2012. Elsevier Ltd.

National Audit Office (NAO), 1996. Space Management in Higher Education: A Good Practice Guide. [Online] Space Management Group Available at: www.smg.ac.uk/documents/NAO_report_1996.doc [Accessed 24 May 2018].

NewCastle University (NCU) \& Higher Education Funding Council for England (HEFCE), 2002. Space Management in Higher Education. Newcastle: HEFCE Newcastle University.

Owolabi, S.O., 1995. Utilisation of Teaching Spaces and Teaching Time at Kumasi Polytechnic. Accra: Ministry of Education and Culture Kumasi Tachnical University.

Petty, L., 2016. The Hub. [Online] High speed training ltd. Available at: https://www.highspeedtraining.co.uk/hub/softhard-facilities-management-difference/ [Accessed 26 May 2018].

Porth, S., 2002. Strategic Management: A cross functional approach. New Jersey: Prentice Hall.

Portman, J., 2014. Building Services Design Management. Oxford: Wiley-Blackwell.

Rahman, A.M.S., Ali, H.M., Sipan, I. \& Mohammed, M.A., 2015. Space utilization model for higher education institutions. Journal of Technology (Science and Engineering), 75(10), pp.163-70. 
Razali, M.N., 2007. The Role of Facilities Management Information System (FMIS) in Construction Project Management. In Management in Construction Researchers Association Conference (MICRA). Kuala Lumpur, 2007. ResearchGate.

Silima, I.-h.J., 2018. Towards optimizing the use of limited lecture space in Ardhi University. Inter view with officer from the Directorate of Estate Services (DES). Dar es Salaam: Ardhi University.

Space Management Group (SMG), 2006. Space utilisation: Practice, Performance and Guidelines. [Online] Space Management Group Available at: https://www.google.com/url?sa=t\&rct=j\&q=\&esrc=s\&source=web\&cd=1\&cad=rja\&uact=8\&ved=0ahUKEwil2o $2 \mathrm{jh} 7 \mathrm{j}$ YAhVGPRQKHdEhBYcQFggpMAA\&url=http\%3A\%2F\%2Fwww.smg.ac.uk\%2Fdocuments\%2Futilisation.pdf\&usg =AOvVaw02zGsfa56SYGMghuOm3cc2 [Accessed 29 December 2017].

Ssempebwa, J., 2011. Evaluating the utilization of resources in higher education institutions: The case of teaching space at a Ugandan university. Evaluation Journal, 17(3), pp.247-59.

Sudha, T., 2013. Total quality Management in higher learning education institutions. International Journal of Social Science \& Interdisciplinary Research, 2(6), pp.121-32.

TCU, 2014. Quality Assurance, General Guidelines and Minimum Standards for Provision of University Education in Tanzania. 2nd ed. Dar es Salaam: TCU.

TEFMA, 2009. Space Planning Guideline. 3rd ed. Sydney: TEFMA Publication.

Terrtiary Education Facilities Management Association (TEFMA), 2009. Space Planning Guideline. 3rd ed. Sydney: TEFMA Publication.

Titto, C., 2018. Towards optimizing the use of limited lrcture space in Ardhi University. Interview with officer from the Directorate of Planning and Development (DPD). Dar es Salaam: Ardhi University.

Wanlaya, P., 2006. The Scope of Facility Management. Nakhara, 6, pp.75-90. Available at: www.aj.arch.chula.ac.th/nakhara/files/article/165-359-1-PB.pdf [Accessed 18 May 2018]. 